Man and Nature

L'homme et la nature

\title{
Clarissa's Ignorance
}

\section{Bruce Stovel}

Volume 11, 1992

URI : https://id.erudit.org/iderudit/1012675ar

DOI : https://doi.org/10.7202/1012675ar

Aller au sommaire du numéro

Éditeur(s)

Canadian Society for Eighteenth-Century Studies / Société canadienne d'étude du dix-huitième siècle

ISSN

0824-3298 (imprimé)

1927-8810 (numérique)

Découvrir la revue

Citer cet article

Stovel, B. (1992). Clarissa's Ignorance. Man and Nature / L'homme et la nature, 11, 99-110. https://doi.org/10.7202/1012675ar

Copyright $@$ Canadian Society for Eighteenth-Century Studies / Société canadienne d'étude du dix-huitième siècle, 1992
Ce document est protégé par la loi sur le droit d'auteur. L’utilisation des services d'Érudit (y compris la reproduction) est assujettie à sa politique d'utilisation que vous pouvez consulter en ligne.

https://apropos.erudit.org/fr/usagers/politique-dutilisation/
Cet article est diffusé et préservé par Érudit.

Érudit est un consortium interuniversitaire sans but lucratif composé de l’Université de Montréal, l'Université Laval et l'Université du Québec à Montréal. Il a pour mission la promotion et la valorisation de la recherche. https://www.erudit.org/fr/ 


\section{Clarissa's Ignorance}

A very unusual moment occurs in the first section of Richardson's massive novel Clarissa. Yet another day of overheard conversations, angry letters, and face-to-face confrontations has left the heroine drained and yet agitated; 'I have been forced to try to compose my angry passions at my harpsichord,' she writes to her confidante Anna Howe, and what she plays is her own setting of the final three stanzas of 'that charming ODE TO WISDOM, which does honour to our sex, as it was written by one of it.' (In fact, its author was Richardson's contemporary, Elizabeth Carter.) $)^{2}$ This is a rare moment of peace and harmony for the heroine (emphasized by the presence, in the first editions of the novel, of the music that Clarissa supposedly composed and performed). Even more, it is unusual because Clarissa quotes the whole of this sixteenstanza ode and in so doing presents herself through it; in general, Clarissa rarely cites or alludes to works of literature - unlike her counterpart Lovelace, who regularly defines himself through the medium of his favourite poets and playwrights (he quotes seven passages of poetry in his first letter alone). Clarissa turns to this ode, it seems, for two reasons. On the one hand, it expresses her sense that she is in great need of wisdom in her present crisis; the second-last stanza of the poem, and thus the second of the three she set to music, is a prayer for help:

Oh send her [i.e., Wisdom's] sure, her steady ray

To regulate my doubtful way,

Through life's perplexing road;

The mists of error to control,

And through its gloom direct my soul

To happiness and good. (234)

On the other hand, Clarissa, like the poem's speaker, is confident that wisdom can see through, and overcome, false appearances; the poem's final stanza reads: 
Beneath her clear discerning eye

The visionary shadows fly

Of folly's painted show.

She sees through ev'ry fair disguise,

That all, but VIRTUE's solid joys,

Is vanity and woe. (234)

Clarissa's quiet confidence is understandable: until this point in her life she would seem to have been preternaturally wise. Anna Howe repeatedly speaks of Clarissa's superior, indeed exemplary, intellectual powers; in fact, Anna's tribute to her friend at the novel's end is a detailed account of Clarissa's education and her ability to apply her intellect to the humble tasks of daily life. Before the action of the novel begins, Clarissa has reasoned her friend Anna out of her infatuation with the rake Sir George Colmar, and Clarissa's unremitting campaign throughout the novel to argue Anna around to accepting the sobersided Mr. Hickman finally succeeds, though only after Clarissa's death. Clarissa's status as precociously prudent is summed up in a strange episode that has occurred some months before the novel's opening: Clarissa has written a letter 'personating an anonymous elderly lady ... to Miss Drayton's mamma, who, by her severity and restraints, had like to have driven the young lady into the very fault against which her mother was most solicitous to guard her' (246). A long excerpt from this letter is quoted in the novel, and it is so judicious, so sympathetic to both parties, and so forcefully expressed that we have no trouble understanding why Mrs. Drayton immediately changed her ways.

My contention, however, is that Clarissa is desperately and pathetically ignorant. The feminine code which she embodies requires that she be kept innocent of sordid actuality; Richardson presents women as the victims of a double standard in mental and social, as well as simply sexual, life. Clarissa's predicament is symbolized by her position at Mrs. Sinclair's house during the central section of the novel: Clarissa, intent upon delicate moral discriminations and justifications, cannot see that she is a prisoner in a brothel. In the same way, she had never realized while engaged in a war of wills with her family that Lovelace, through his agent Joseph Leman, was actually in control at Harlowe-Place. Clarissa's ignorance of the true state of things in both houses is symbolic: that which she has no way of knowing is not simply how Joseph Leman has worked upon James Harlowe, nor the true identity of Mother Sinclair and her nieces, but rather the real nature of Lovelace: his deviousness, his deceitfulness, his cruelty, his spite. Clarissa is also ignorant of her own emotions. She never grasps how deeply she resents 
her brother and sister; even more importantly, Clarissa is ignorant for much of the novel of her own increasingly strong love for Lovelace. According to Anna Howe's final letter, one of Clarissa's moral tenets is that 'The darkest and most contemptible ignorance is that of not knowing one's self' (1466); yet Clarissa cannot recognize her love, which is so evident to everyone around her, because she believes that love is a rational emotion that, in a good person, is a moral response to the worth of another. The novel shows an intelligent and perceptive young woman disabled by her uncompromising adherence to the very code that is supposed to protect her - to what Clarissa calls at one point 'all the fences that a careful education has surrounded us by' (II, 438). As Belford says in his first letter to Lovelace, 'In this lady's situation, the trial is not a fair trial' (501); or, as Colonel Morden says of Clarissa near the novel's end, 'her prudence (eminent as it was) being the effect of constitution rather than experience, ... she might not be apprehensive of bad designs in a man she loved' (1280).

In this essay, I would like to explore this question of Clarissa's ignorance. It seems that this ignorance is of two kinds: to use the book's terms, a lack of prudence injudging those around her, on the one hand, and a lack of self-knowledge, on the other. More specifically, Clarissa misjudges the true nature and motives of both her brother and of Lovelace; these two blind spots are matched by two failures of self-knowledge: she does not understand her own resentment of her siblings nor her strong attraction to Lovelace. In every case, Clarissa's lack of knowledge is the inevitable result of her pious education, her sheltered way of life, and her idealism. Her ignorance is the mainspring of the novel's plot, the source of much of its dramatic intensity, and to a large degree what Clarissa is describing in her repeated references throughout the novel as 'a strange concurrence of unhappy causes' (1301), 'a perverse fate which no one of us are able to resist' (333). There are two reasons why an attempt to define Clarissa's ignorance is especially worthwhile. One is that, as Siobhan Kilfeather points out in a recent survey of Richardson criticism, Clarissa is very difficult to comprehend, not only because of its length and the glacial slowness with which its plot advances, but also because of the absence of regular, external divisions marking rememberable stages in the action; she notes that even a whole book devoted to Richardson's novel seems to make contact with only a small proportion of its substance. ${ }^{3}$ Another reason to look more closely at Clarissa's ignorance is that much Richardson criticism takes the heroine at face value. Elizabeth Bergen Brophy, for instance, in her Samuel Richardson: The Triumph of Craft, says, 'Clarissa has usually been more accurate in her judgments than Anna Howe.... By her breadth and accuracy of moral judgment, Richardson establishes [Clarissa] as a fitting exemplar. ${ }^{4}$ And John Hall Stevenson, in a recent 
article which argues that Richardson was concerned in Pamela and Clarissa to overturn the assumptions of Locke's empiricism, says, 'Clarissa's judgment is both perfectly naive and completely accurate. ${ }^{, 5}$

In fact, however, Clarissa's judgments of the two most important men in her life, her brother James and her suitor Lovelace, are disastrously mistaken. In the first case, that of James, she underestimates her brother's devious intelligence. Misled by his fiery behaviour and his rude breaches of decorum, she assumes that James is simply greedy and socially ambitious, the starkest and most flagrant instance of what she calls 'the family failing.' She repeatedly reproves him for his violent behaviour, his lack of self-control and self-knowledge; at one point, for instance, she writes to him:

Let me take the liberty further to observe, that the principal end of a young gentleman's education at the university is to learn him to reason justly, and to subdue the violence of his passions. I hope, brother, that you will not give room for anybody who knows us both to conclude that the toilette has learned the one more of the latter doctrine, than the university has taught the other. I am truly sorry to have cause to say, that I have heard it often remarked that your uncontrolled passions are not a credit to your liberal education. (138)

What Clarissa is ignorant of here is that James has embarked on an ingenious strategy of driving her into overt rebellion; fuelled by his envy of Clarissa and a spiteful determination to make her suffer, his elaborate mobilization of the Harlowe family in support of the marriage proposals of the hateful Mr. Solmes actually aims to drive Clarissa into overt rebellion - and so into ejecting herself from the family. It is intensely ironic that Clarissa writes to Lovelace agreeing to elope with him immediately after overhearing her brother and sister exulting over the success of their schemes: 'I heard the barbarous designer say, speaking to my sister: This works charmingly, my dear sister.... Let us keep it up. The villain is caught in his own trap! Now she must be what we'd have her be' (340). Clarissa, enraged, misunderstands and so rushes into the very trap that the 'barbarous designer' has set. As Anna Howe says immediately after the elopement, 'It is, no doubt, the very thing they aimed to drive you to' (405).

What is especially interesting is that Clarissa several times raises the possibility that James may indeed be this devious and malicious, but she cannot bring herself to accept such terrible knowledge. Near the outset, when she summarizes the family plan to Anna, she writes, "This is the bright side that is turned to my father and uncles to captivate them; but I am afraid that my brother's and sister's design is to ruin me with them at 
any rate' (81). Six days later, however, she writes to Anna, 'Can such measures be supposed to soften? - But surely they [i.e., her family] can only mean to try to frighten me into my brother's views' [i.e., into accepting Solmes] (122). Clarissa's tentative and reluctant tone here is perhaps even more important than her conclusion. This divided tone continues: on the one hand, she says to Anna at one point, 'it seems plain to me that [my brother and sister] will work but half their ends if they do not deprive me of my father's and uncles' favour' (219), but a few days later she writes that her brother and sister must be confident that she will eventually agree to marry Solmes, 'since they must think that, otherwise, they give me provocations enough to take some rash step, in order to free myself from a treatment so disgraceful; and which (God forgive me, if I judge amiss!), I am afraid my brother and sister would notbe sorry to drive me to take' (281). Clearly, observation and judgement force upon her an awareness that she cannot bring herself to accept: it cannotbe that her own brother and sister could be so diabolic. Preferring to trust in reason and morality, Clarissa makes counter-proposal after counter-proposal to her family (the final one, significantly, is that there be a formal debate in writing between her and her brother: 'Any impartial person, your late tutor for instance, or the pious and worthy Dr. Lewen, may judgebetween us' [227]). Paradoxically, then, Clarissa's ignorance is not a blank, but consists of theoretical knowledge, knowledge that is so alien to all that she knows and believes that, for practical purposes, it amounts to ignorance.

This same paradoxical state of theoretical knowledge, indistinguishable from ignorance, also characterizes Clarissa's misjudgment of Lovelace. Only ten pages after the novel begins she hears that he has been 'a sad gentleman as to women ... a great plotter ... he lived a wild life in town' (50). But the double standard ensures that such statements reach Clarissa only in vague and general form; even when Colonel Morden, the one upright Harlowe, writes a letter of dire warning to Clarissa, his charge that Lovelace was guilty of libertine misbehaviour in Italy is extraordinarily unspecific: 'There were, in short, some liberties in which he indulged himself, that endangered his person and his liberty, and made the best and most worthy of those who honoured him with their notice give him up' (563). Clarissa in some sense accepts this verdict: when she draws up a list of sixteen arguments in Lovelace's disfavour, the seventh and eighth are the following: 'that he has a very immoral character as to our sex; that knowing this, it is a high degree of impurity to think of joining in wedlock with such a man' (183). At the same time, all of these notions are so alien to her experience that she can find no way to accept and act upon them. As she says in one of the fragments she writes to Lovelace after the rape, 'I knew not, but by report, any flagrant instances of your vileness.... I judged of [your heart] by my own' (892). 
Clarissa thus fails to understand how devious and clever Lovelace is. An early example occurs when Lovelace visits the family church unexpectedly one Sunday, frightening and incensing the Harlowes. Clarissa cannot see that Lovelace has everything to gain from the family's reaction, which is to bear down harder on her; instead, she laments 'the unseasonableness of this rash man's presence at our church' (141). Similarly, she fails regularly to see Lovelace's hidden aims: when his threats make the family decide against a common move to Uncle Anthony's house; when Lovelace promises that 'his whole view at present is to free me from my imprisonment; and to restore me to my own free will' (349); when he inveigles her into suggesting that she live in London after her flight; and when he tricks her into choosing to live at Mrs. Sinclair's house. Lovelace's letters to his friend Belford reveal how far out of her depth Clarissa is; at first intermittently punctuating and undercutting the Clarissa-Anna letters, they slowly come to dominate, and eventually extinguish altogether, the female correspondence. After she selects her London lodgings, we hear Lovelace gloat: 'Who could forbear smiling to see my charmer, like a farcical dean and chapter, choose what was before chosen for her. Silly little rogues! to walk out into by - paths on the strengths of their own judgments! - when nothing but experience can teach them how to disappoint us, and learn them grandmother-wisdom!' (472). Clarissa's judgment proves again and again transparent to Lovelace: he sees how much she longs for respectability and so provides letters from his relations; he uses her refusal to admit to her family that her flight with Lovelace was unintentional to keep hostilities alive; he takes advantage of her perception that delicacy requires her not to accept too eagerly a marriage proposal from him; when she finally does understand where she is, after the fire-scene, and escapes from Mother Sinclair's, he has no trouble tracing her to Hampstead - Clarissa had been there with him more than once and, as she confesses to Anna, 'I knew not what to do better' (755).

And if Clarissa fails to understand Lovelace's designs, she is even more ignorant of his moral identity, his character. She could not bring herself to believe that her brother was all that bad, but during the first half of the novel, she repeatedly attempts to persuade Anna, and herself, that Lovelace is not bad, but good. Here are four of many such attempts:

(1) do you really think Mr. Lovelace can have a very bad heart? why should there not be something in blood in the human creature, as well as in the ignobler animals? None of his family are unexceptionable - but himself, indeed. The ladies' characters are admirable. (169) 
(2) Will Lovelace's wife be the only person to whom he will not pay the grateful debt of civility and good manners? He is allowed to be brave: who ever knew a brave man, if a man of sense, an universally base man? (182)

(3) Nor is it a very bad indication that he has such moderate notions of that very high prerogative in husbands, of which we in our family have been accustomed to hear so much. (I, 180)

(4) Surely ... the man who would resent, as the highest indignity that could be offered to a gentleman, the imputation of a wilful falsehood would not be guilty of one? (247)

The logical surface here only highlights Clarissa's child-like innocence. And once she is living in London under Lovelace's power, she becomes even more determined to absolve him from blame. At one point, for instance, she writes that she must believe Lovelace's vows of reform: 'may I not, from one very sad reflection, think better of him; that I am thrown too much in his power to make it necessary for him (except he were to intend the very utmost villainy by me) to be such a shocking hypocrite? - He must, at least, be in earnest, at the time he gives the better hopes' (452). Later, she goes even further: 'does not [his natural dignity of manner] show that he was born innocent, as I may say; that he was not naturally the cruel, the boisterous, the impetuous creature which the wicked company he may have fallen into have made him' (545). Clarissa has forgotten the Fall - ironically, the very story she is re-enacting.

At the same time, however, just as with her brother, Clarissa knows much more than she can bring herself to admit. At some level, her mind has grasped the essential facts about Lovelace, as we learn from the dream that she has the night after she impulsively promises to go away with him:

Methought my brother, my uncle Antony, and Mr. Solmes had formed a plot to destroy Mr. Lovelace; who discovering it turned all his rage against me, believing I had a hand in it. I thought he made them all fly into foreign parts upon it; and afterwards seizing upon me, carried me into a churchyard, and there, notwithstanding all my prayers and tears, and protestations of innocence, stabbed me to the heart, and then tumbled me into a deep grave ready dug, among two or three half-dissolved carcases; throwing in the dirt and earth upon me with his hands, and trampling it down with his feet. (343) 
Ironically, Clarissa disregards the dream, telling herself, 'why should I, who have such real evils to contend with, regard imaginary ones?' Clearly, however, her ignorance about Lovelace coexists in her mind with an astonishingly complete grasp of truths about him that she cannot realize, make real, because such truths lie outside her own experience. She does not yet know that the words 'he has a very immoral character as to our sex' can mean 'he stabbed me to the heart.' The fact that the novel never does allow us to witness that stabbing - the rape that is at its heart as well as Clarissa's - emphasizes this disjunction between violent physical actuality and Clarissa's mental world. ${ }^{6}$

The double standard also, it seems, makes self-knowledge much harder for women to attain. If Clarissa's feminine education and way of life keep her judgment in ignorance, they also work to keep her unaware of her own emotions. At one point, counselling Anna to be more forbearing, Clarissa makes the connection between the feminine code and self-ignorance: "Those passions in our sex, which we take no pains to subdue, may have one and the same source with those infinitely blacker passions which we used so often to condemn in the violent and headstrong of the other sex; and which may be heightened in them only by custom, and their freer education. Let us both, my dear, ponder well this thought; look into ourselves, and fear' (550). The suggestion is that men's passions are not only intensified by their education and the male ethos; they are also much more highlighted, more available to scrutiny. We can note that Lovelace is almost suspiciously glib in defining his inner conflicts, while Clarissa's code puts her in a much more difficult position. She has no trouble realizing and formulating her complete revulsion, moral, social, and physical, to Solmes, since such revulsion confirms her self-image as pure, but it is much harder for her to accept the attraction that she feels for Lovelace. When she begins to acknowledge her feelings, the words she uses are significant: 'depending on my own strength; having no reason to apprehend danger from headstrong and disgraceful impulses, I too little, perhaps, cast up my eyes to the Supreme Director' (565).

Clarissa's two crucial failures in self-knowledge correspond to the two blind spots in her judgment: she fails to understand both how deeply she resents her brother and sister, and how much she loves Lovelace. As for the first question, resentment and even envy of James breathes forth from everything she says or writes to him (her letter of rebuke cited above is a good example). Why should he have complete freedom of choice and she none? why should the family's wishes and ambition revolve around him, just because he is the only son and heir? why should he have a fine education and she be limited to the toilette? why should everyone in the family wish his favour and fear losing it above all else? Clarissa asks these 
questions again and again, sometimes explicitly, as when she asks James, as she does several times, 'How would you take it, if you had a brother, who in a like case were to act by you, as you do by me?' (137; cf. 203, 219, 305), and sometimes less overtly, as, for instance, in her frequent attacks on James for failing to take advantage of his privileged education: 'give me leave to tell you, sir, that if humanity were a branch of your studies at the university, it has not found a genius in you for mastering it' (219; cf. the passage from p. 138 quoted above, p. 102).

My point here is not that Clarissa's feminist indignation is unjustified, but rather that she does not realize how deeply she resents and envies her two siblings. In three very similar scenes in the first section of the novel, her mounting fury at their supremacy becomes increasingly evident. When she overhears her brother, her sister, and Solmes 'laughing and triumphing together,' she is 'fired' and writes here brother an angry letter 'while the iron was red hot' (226). Next, she encounters her brother and sister in the garden, 'gay and good humoured ... hand in hand, lover-like,' and her subsequent reflection, 'Oh my cunning brother! - This is his contrivance! ... the triumph in his and my sister's loves to each other, acted before me' (295), drives her first to outrage and then to tears. And, finally, when Clarissa overhears her brother and sister congratulating themselves that 'Now she must be what we'd have her be,' suddenly the impasse within her is broken: 'I dwelt upon their triumphings over me: and found rise in my mind a rancour that I may say was new to me, and which I could not withstand.... Having shook off Betty as soon as I could, I wrote to Mr. Lovelace to let him know, “... That I had come to a resolution to throw myself upon the protection of either of his two aunts, who would afford it me ..."' (341).

But of course the central instance of self-ignorance is Clarissa's inability to admit, for the first half of the novel, that she is in love with Lovelace. Anna Howe repeatedly forces this fact upon her and our attention; my point is that she is kept from self-awareness by her complete submission to her feminine and idealistic code. What kind of person would she be if she were to love someone of whom she cannot approve? That is why she will only admit to 'a conditional kind of liking' $(135,185)$ - conditional, that is, upon Lovelace's character. In the same way, the shrewd and observant Pamela cannot bring herself to recognize her love for Mr. B. for more than half of Richardson's first novel. Richardson added a long paragraph to the third edition of Clarissa in which he spelled out his heroine's dilemma and its basis in her considered beliefs. Clarissa, once again unaware that she has been duped by Lovelace, has just discovered by her great agitation when he seems to be mortally ill how much she cares. She writes to Anna: 
should we not endeavour, as much as we can, as much as human frailty and partiality will permit (where we are not attached by natural ties) to like and dislike as reason bids us, and according to the merit or demerit of the object? If love, as it is called, is allowed to be an excuse for our most unreasonable follies, and to lay level all the fences that a careful education has surrounded us by, what is meant by the doctrine of subduing our passions? But, $\mathrm{O}$ my dearest friend, am I not guilty of a punishable fault, were I to love this man of errors? And has not my own heart deceived me, when I thought I did not? (II, 438)

Clarissa's love, once again something that she has had in her mind but been unable to acknowledge, explains her crucial actions in the novel to this point: her correspondence with Lovelace, her half-willing, halfunwilling elopement with him, her agreeing to live in the same house with him in London, her tentative acceptance of his marriage proposals. In the famous fable with which she summarizes her history after the rape, she not only admits her love - 'A young lady took a great fancy to a young lion, or a bear, I forget which' - but she also takes responsibility for her human nature in a way she had not earlier: 'And who was most to blame, I pray? The brute or the lady? The lady, surely! - For what she did, was out of nature, out of character, at least: what it did, was in its own nature' (891). In that correction of 'nature' to 'character' lies an immense growth in awareness.

By way of conclusion, I would like to make six final observations. The first is that the lapses of judgment and failures of self-knowledge that constitute Clarissa's fate are interpenetrating and feed each other. She misjudges James because of her hatred, she misjudges Lovelace because she loves him. On the other hand, her conduct is ill-judged because she does not understand her own motives. Her heated animosity to James only inflames his own hatred for her, while her refusal to admit what she obviously feels only makes Lovelace more determined to conquer and subdue her.

Furthermore, the two primal emotions that motivate Clarissa, her love and her hatred, also interpenetrate and fuel each other in an ever-intensifying spiral. Her love for Lovelace increases step by step with her revulsion for Solmes and her mounting rage at her brother and sister. In fact, Clarissa's growing hatred for her siblings is itself a form of wounded love: she finds herself treated as an instrument of dynastic policy by those that she had thought loved her. Lovelace has grasped the pattern when he describes Clarissa's flight from Harlowe-Place as 'flying from her love to her love' (400).

A third point is that Clarissa is not entirely mistaken in her judgments of Lovelace. Like her, he is internally divided: if one side of him is intent on subduing her feminine dignity, another genuinely wishes to be 
overcome by her moral goodness. As Mark Kinkead-Weekes has noted, Lovelace's convincing performances as a good man enact one of his potential selves. ${ }^{7}$ Lovelace states this memorably to Belford as the rape approaches: 'What a happy man, in this particular case had I been, had it been given me to be only what I wished to appear to be' (849).

A fourth observation is that Clarissa's ignorance is an important issue only in the first half of the novel. At the exact midpoint, at the end of Volume IV of the original eight volumes, Lovelace overreaches himself by staging a fire in the house in order to invade Clarissa's bedroom at night, and she suddenly sees through him, his designs, and his accomplices. From this point onward, Clarissa is unshaken and increasingly decisive in her rejection of Lovelace - and more and more aware of just what she has done and been. Lovelace, meanwhile, becomes increasingly incompetent and ignorant: outsmarted by his accomplices, undone by his own schemes, at the mercy of, rather than controlling, events. When he recuperates his former self in the only possible way, by stage-managing his own death in a duel, his grand dying words 'LET THISEXPIATE!' both express his remorse and indicate his inability to learn or change.

A fifth point is that Clarissa's new moral and spiritual knowledge is ironic: it seems to disqualify her for the moral life, and indeed for life of any sort. There is a poignant symbol of this irony in Anna Howe's letter of eulogy. Anna recounts that Clarissa's life before the events of the novel had been so carefully organized that she made daily entries in a sort of moral account-book: so many hours per day were to be devoted to reading and writing letters, so many to visiting the poor, and so forth; a continuing balance of moral debits and credits had to be maintained. This book embodies Clarissa's genteel education and feminine ideals. However, Anna says, she finds that Clarissa had subsequently written in the book, 'at the extreme edge of the paper, with a fine pen, and in the dearest creature's smallest hand,' the words: 'April 10. The account concluded! - And with it, all my worldly hopes and prospects!!!' (1472). April 10, of course, is the day that Clarissa fled from her family home; it is also the date that she inscribes as the day of her death on her coffin. When her ignorance ends, her death begins.

A final point is that this approach to the novel allows us to see Clarissa as a tragic figure, like Hardy's Tess destroyed by her loyalty to a social code that she has internalized, but in the end one more sinned against than sinning. Put more simply, it is easy to forget that Clarissa is an eighteenyear-old girl. Many critics, Ian Watt being perhaps the mosteminent, see both protagonists as psychological cases, a view summed up wittily by John Traugott: 'If one would not be a sadist with Lovelace, no more would one be a masochist with Clarissa. ${ }^{8}$ Luckily, the choice is entirely hypothetical, but I suspect that any tragedy with emotional impact makes us 
feel exactly the reverse: better to undergo self-destruction with Lear or Othello than to prey on others like Goneril or Iago. What makes Clarissa doubly tragic, of course, is that Lovelace is not simply a villain; in his own tormented way he is, like Clarissa, destroyed by his own finest qualities. But that is another story, and Lovelace's ignorance the stuff of another essay.

BRUCE STOVEL

University of Alberta

Notes

1 Clarissa, or The History of a Young Lady, ed. Angus Ross (Harmondsworth: Penguin, 1985), 231. Subsequent quotations from this edition will be included within my text, with page numbers in parentheses. This edition is a reprint of the first edition of 1747-48; the revised and expanded third edition of 1751 is quoted in two cases below from the four-volume Everyman edition (London: Dent, 1962), with volume and page numbers in parentheses.

2 See T.C. Duncan-Eaves and Ben D. Kimpel, Samuel Richardson: A Biography (Oxford: Clarendon Press, 1971), 214-16.

3 Siobhan Kilfeather, 'The Rise of Richardson Criticism,' in Samuel Richardson: Tercentenary Essays, ed. Margaret Anne Doody and Peter Sabor (Cambridge: Cambridge University Press, 1989), 253-4.

4 Elizabeth Bergen Brophy, Samuel Richardson: The Triumph of Craft (Knoxville: University of Tennessee Press), 102, 99.

5 John Allen Stevenson, "'Never in a Vile House": Knowledge and Experience in Richardson,' Literature and Psychology, 34 (1988), 4-16; p. 5.

6 John Preston, in his The Created Self: The Reader's Role in Eighteenth-Century Fiction (London: Heinemann, 1970), speaking of the gaps in narration which occur at the time of Clarissa's flight and of the rape, remarks, 'Some things the mind cannot accommodate; they must be left as a fracture in experience, reduced to non-existence' (48). Both William B. Warner, in Reading 'Clarissa': The Struggles of Interpretation (New Haven: Yale University Press, 1979), and Terry Castle, in Clarissa's Ciphers: Meaning and Disruption in Richardson's 'Clarissa' (Ithaca: Cornell University Press, 1982), develop the notion that Clarissa's perceptions are mental constructs - though 'aggressive' and 'irreducibly self-centered' ones to Warner (38) and 'naive' and 'sincere' ones to Castle (21).

7 Mark Kinkead-Weekes, Samuel Richardson: Dramatic Novelist (Ithaca: Cornell University Press, 1973), 153, 186-7. Martin Price discusses Lovelace in very similar terms in his To the Palace of Wisdom: Studies in Order and Energy from Dryden to Blake (Carbondale: Southern Illinois University Press, 1964), 277-9.

8 John Traugott, 'Clarissa's Richardson: An Essay to Find the Reader,' in English Literature in the Age of Disguise, ed. Maximillian E. Novak (Berkeley, Los Angeles, London: University of California Press, 1977), 157-208; p. 207. 